\title{
PENERAPAN MODEL PEMBELAJARAN OSBORN UNTUK MENINGKATKAN PRESTASI BELAJAR PESERTA DIDIK PADA POKOK BAHASAN KESETIMBANGAN ION DAN PH LARUTAN GARAM
}

\author{
Lutfiah Azmi*, Betty Holiwarni, Rasmiwetti
}

Program Studi Pendidikan Kimia, Fakultas Keguruan dan Ilmu Pendidikan Universitas Riau, Kampus Binawidya KM 12,5, Pekanbaru 28293, Riau, Indonesia.

\begin{tabular}{l} 
Informasi Artikel \\
\hline Sejarah Artikel: \\
Diterima: 20-05-2019 \\
Disetujui : 27-01-2020 \\
Dipublikasikan: 28-01-2020 \\
\hline Keywords: \\
Osborn Learning Model, \\
Learning Achievement, \\
Ion Equelibrium and pH of \\
Salt Solution, \\
Learning achievement
\end{tabular}

Keywords:

Osborn Learning Model,

Learning Achievement, Salt Solution,

Learning achievement

\begin{abstract}
A b s t r a k
Penelitian bertujuan untuk meningkatkan prestasi belajar peserta didik pada pokok bahasan kesetimbangan ion dan $\mathrm{pH}$ larutan garam di kelas XI IPA SMAN 14 Pekanbaru. Jenis penelitian ini adalah penelitian eksperimen dengan desain pretest-posttest. Penelitian dilaksanakan di SMAN 14 Pekanbaru. Sampel dari penelitian adalah peserta didik kelas XI IPA 1 sebagai kelas eksperimen dan peserta didik pada kelas XI IPA 3 sebagai kelas kontrol. Kelas eksperimen adalah kelas yang diterapkan model pembelajaran Osborn sedangkan kelas kontrol tidak diberi perlakuan. Teknik analisis data digunakan adalah uji-t. Berdasarkan hasil uji analisis data diperoleh thitung $>$ ttabel yaitu $7,25>1,67$, artinya penerapan model pembelajaran Osborn dapat meningkatkan prestasi belajar peserta didik pada pokok bahasan kesetimbangan ion dan $\mathrm{pH}$ larutan garam di kelas XI IPA SMA Negeri 14 Pekanbaru dengan kategori peningkatan prestasi belajar pada kelas eksperimen berdasarkan Skor $(N$-Gain) tergolong tinggi yaitu 0,73 .
\end{abstract}

\begin{abstract}
A b s tract
The research aims to improve student learning achievement on the subject of ion equilibrium and pH of salt solution in class XI IPA SMAN 14 Pekanbaru. This type of research is an experimental study with a pretestposttest design. The research was conducted at SMAN 14 Pekanbaru. The sample from the study was students of class XI IPA 1 as an experimental class and students in class XI IPA 3 as a control class. The experimental class is the class applied to the Osborn learning model while the control class is not treated. The data analysis technique used is the t-test. Based on the results of the data analysis test, tcount> ttable is 7.25> 1.67, meaning that the application of Osborn's learning model can improve student learning achievement on the subject of ion equilibrium and $\mathrm{pH}$ of salt solution in class XI IPA 14 of SMA Negeri 14 with categories of achievement improvement learning in the experimental class based on Score (N-Gain) is high, which is 0.73.
\end{abstract}

\footnotetext{
*Alamat korespondensi:

E-mail: luthfiahazmi6@gmail.com (LA)

No. Hp: +6282286574840
} 


\section{PENDAHULUAN}

Kesetimbangan ion dan $\mathrm{pH}$ larutan garam merupakan salah satu materi yang diajarkan pada mata pelajaran kimia di kelas XI IPA SMA. Informasi yang diperoleh dari salah seorang guru kimia kelas XI IPA di SMA Negeri 14 Pekanbaru, tahun ajaran 2017/2018 rata-rata nilai ulangan peserta didik pada pokok bahasan Kesetimbangan ion dan $\mathrm{pH}$ larutan garam belum memenuhi Kriteria Ketuntasan Minimum (KKM) yaitu hanya $41,18 \%$ peserta didik yang tuntas dengan Kriteria Ketuntasan Minimum (KKM) yang ditetapkan sekolah untuk pokok bahasan Kesetimbangan ion dan $\mathrm{pH}$ larutan garam adalah 75 dikarenakan pembelajaran yang ada kurang didominasi peserta didik, dimana peserta didik hanya mendengarkan penjelasan dari guru saja sehingga kurangnya aktivitas dan keterlibatan peserta didik dalam proses pembelajaran.

Proses pembelajaran melibatkan proses interaksi antar peserta didik, antara peserta didik dan pendidik, dan antara peserta didik dan sumber belajar lainnya pada suatu lingkungan belajar yang berlangsung secara edukatif, agar peserta didik dapat membangun sikap, pengetahuan dan keterampilannya untuk mencapai tujuan yang telah ditetapkan. Keberhasilan proses belajar mengajar dapat dilihat dari pencapaian tujuan pembelajaran. Keberhasilan pencapaian tujuan pembelajaran tidak terlepas dari peran guru. Guru sebagai fasilitator, motivator dan pembimbing peserta didik dalam meningkatkan kemampuan peserta didik untuk memahami materi mengharuskan guru memiliki strategi, metode, media dan model yang tepat, sehingga proses pembelajaran dapat berlangsung efektif.

Model pembelajaran sangat mempengaruhi suasana belajar peserta didik sehingga dapat berpengaruh pada prestasi belajar peserta didik. Pemilihan model pembelajaran disesuaikan dengan mata pelajaran agar menarik dan memotivasi peserta didik terhadap materi pelajaran, termasuk dalam mata pelajaran kimia. Kesetimbangan ion dan $\mathrm{pH}$ larutan garam merupakan salah satu materi yang diajarkan pada mata pelajaran kimia di kelas XI IPA SMA. Informasi yang diperoleh dari salah seorang guru kimia kelas XI IPA di SMA Negeri 14 Pekanbaru, tahun ajaran 2017/2018 ratarata nilai ulangan peserta didik pada pokok bahasan Kesetimbangan ion dan $\mathrm{pH}$ larutan garam belum memenuhi Kriteria Ketuntasan Minimum (KKM) yaitu hanya 41,18\% peserta didik yang tuntas dengan Kriteria Ketuntasan Minimum (KKM) yang ditetapkan sekolah untuk pokok bahasan Kesetimbangan ion dan $\mathrm{pH}$ larutan garam adalah 75 dikarenakan pembelajaran yang ada kurang didominasi peserta didik, dimana peserta didik hanya mendengarkan penjelasan dari guru saja sehingga kurangnya aktivitas dan keterlibatan peserta didik dalam proses pembelajaran.

Dalam Pembelajaran di sekolah, guru juga sudah melaksanakan metode diskusi, tetapi belum berjalan efektif hanya beberapa peserta didik yang tertarik dan ikut berdiskusi. Peserta didik masih canggung atau kaku dalam diskusi yang telah diterapkan oleh guru dan peserta didik masih banyak yang pasif sehingga menyebabkan materi pelajaran tidak dapat dipahami secara utuh dan berdampak pada prestasi belajar peserta didik yang di bawah KKM. Apabila guru bertanya, hanya sebagian peserta didik yang aktif menjawab dan lebih didominasi oleh peserta didik yang berkemampuan tinggi ataupun yang memiliki keberanian untuk berbicara saja. Akibatnya, tidak semua peserta didik aktif dalam proses pembelajaran. Kurangnya keaktifan peserta didik dalam pembelajaran ini menyebabkan konsep pelajaran yang dipelajari tidak tertanam kuat dalam ingatan peserta didik, sehingga prestasi belajar peserta didik pun menjadi rendah.

Mengatasi masalah di atas, guru dituntut agar mampu memilih dan menerapkan model pembelajaran yang dapat merangsang peserta didik lebih aktif berpartisipasi dalam pembelajaran, sehingga dapat meningkatkan prestasi belajarnya. Dengan peserta didik menjadi aktif belajar dapat mengurangi kebosanan dan menumbuhkan minat belajar peserta didik. Salah satu alternatif model 
pembelajaran yang diharapkan dapat menyelesaikan permasalahan tersebut adalah dengan menerapkan 0model pembelajaran Osborn.

Model pembelajaran Osborn adalah suatu model pembelajaran dengan menggunakan metode atau teknik brainstorming. Metode Brainstorming adalah suatu metode yang dilaksanakan oleh guru di dalam kelas dengan melontarkan suatu masalah kemudian siswa menjawab, menyatakan pendapat, atau memberi komentar sehingga memungkinkan masalah tersebut berkembang menjadi masalah baru, atau dapat diartikan pula sebagai satu cara untuk mendapatkan banyak ide dari sekelompok manusia dalam waktu yang singkat (Roestiyah, 2012).

Pembelajaran dengan menggunakan model Osborn merupakan salah satu teknik pembelajaran dimana peserta didik bebas berpendapat dalam kelompoknya untuk menemukan solusi dari suatu permasalahan dengan mengumpulkan ide dari setiap anggota kelompoknya. Kemudian secara berkelompok peserta didik diajak mengumpulkan data melalui buku referensi atau melakukan pengamatan dengan eksperimen di laboratorium untuk pemecahan masalah. Dalam hal ini peserta didik diberikan pengalaman yang nyata dan dapat memberi penjelasan tentang kesesuaian antara dugaan dengan yang sesungguhnya terjadi (Suparno, 2007). Penelitian ini bertujuan untuk mengetahui peningkatan prestasi belajar peserta didik dan kategori peningkatan prestasi belajar peserta didik dengan penerapan model pembelajaran Osborn pada pokok bahasan kesetimbangan ion dan $\mathrm{pH}$ larutan garam di kelas XI SMA.

\section{METODE PENELITIAN}

Penelitian dilaksanakan disalah satu SMA di Pekanbaru pada semester genap tahun ajaran 2018/2019. Waktu pengambilan data dilakukan pada bulan Maret-April 2019. Populasi dalam penelitian adalah seluruh peserta didik kelas XI IPA SMA Negeri 14 Pekanbaru yang terdiri dari 4 kelas yaitu XI IPA 1, XI IPA 2, XI IPA 3, dan XI IPA 4. Sampel diambil berdasarkan hasil analisis uji normalitas dan uji homogenitas tes nilai ulangan asam basa. Dari uji normalitas dan uji homogenitas diketahui bahwa kelas XI IPA 1 dan XI IPA 3 berdistribusi normal dan mempunyai kemampuan yang sama (homogen), maka kedua kelas tersebut dijadikan sebagai sampel. Diperoleh Kelas XI IPA 1 sebagai kelas eksperimen dan kelas XI IPA 3 sebagai kelas kontrol.

Tabel 1. Tahapan Model Pembelajaran Osborn Secara Umum (Luhfiyati, 2016)

\begin{tabular}{ll}
\hline \multicolumn{3}{c}{ Kegiatan Pembelajaran } & $\begin{array}{c}\text { Tahapan } \\
\text { Model Osborn }\end{array}$ \\
\hline$>$ Kegiatan Awal \\
- Guru mengucapkan salam. \\
- Guru menunjuk salah satu peserta didik memimpin doa, \\
kemudian guru memeriksa kehadiran peserta didik, \\
kebersihan dan kerapian kelas. \\
- \\
Peserta didik diminta duduk di dalam kelompok yang terdiri \\
dari 4 atau 5 orang yang telah ditentukan sebelumnya. \\
- Guru membimbing jalan 25iker peserta didik dengan \\
menyampaikan konsep yang berkaitan pada materi \\
sebelumnya yang akan dihubungkan dengan konsep pada \\
materi yang akan dipelajari kepada peserta didik. \\
Guru memotivasi peserta didik dengan menampilkan gambar \\
orang yang sedang sakit maag kemudian diberikan obat \\
maag sehingga sakit maagnya perlahan hilang. \\
\hline
\end{tabular}




\section{Kegiatan Pembelajaran}

Tahapan

Model Osborn

- Guru menyampaikan tujuan pembelajaran.

\section{Kegiatan Inti}

- Guru membagikan lembar kerja kepada peserta didik dan meminta peserta didik untuk membacanya terlebih dahulu.

- Peserta didik membeca lembar kerja yang diberikan

- Guru menggambarkan kembali masalah yang telah disampaikan diawal pembelajaran kepada peserta didik yang berkaitan dengan reaksi netralisasi kedalam LKPD

- Peserta didik mengidentifikasi setiap masalah yang diberikan dalam LKPD secara individu

- Peserta didik merumuskan penyelesaian yang berkaitan dengan reaksi netralisasi pada LKPD secara individu

\section{Orientasi}

- Peserta didik menuliskan gagasan tentang penyelesaian masalah secara individu, setelah itu semua gagasan pemecahan masalah masing-masing individu didiskusikan dalam kelompok dan gagasan penyelesaian masalah yang paling tepat menurut kelompoknya dituliskan dalam LKPD

- Peserta didik membuktikan gagasan dengan melakukan percobaan yang ada di LKPD secara berkelompok

- Guru meminta peserta didik berdiskusi untuk memperluas konsep dan mengolah data/informasi yang telah didapat dengan mengerjakan LKPD, setiap anggota kelompok bertanggungjawab atas terselesaikannya LKPD tersebut.

- Peserta didik mempresentasikan hasil LKPD di depan kelas

Sintesis

- Peserta didik dari kelompok lain menanggapi, mengoreksi atau menambahkan yang disampikan temannya.

- Guru memutuskan gagasan/ pendapat yang terbaik bersama Verifikasi peserta didik

\section{Kegiatan Akhir}

- Guru bersama-sama dengan peserta didik menyimpulkan secara keseluruhan materi pelajaran yang telah dipelajari.

- Guru memberikan kesempatan kepada peserta didik untuk menanyakan materi yang belum dipahami

- Guru memberikan soal evaluasi kepada peserta didik.

- Guru menugaskan peserta didik untuk membaca materi yang akan dipelajari pada pertemuan selanjutnya.

Bentuk penelitian adalah penelitian eksperimen dilakukan terhadap dua kelas dengan Desain Randomized Control Group Pretest-Posttest seperti Tabel 2. 
Tabel 2. Rancangan Penelitian (Suharsimi, 2013)

\begin{tabular}{lccc}
\hline Kelas & Pretest & Perlakuan & Posttest \\
\hline Eksperimen & $\mathrm{T}_{0}$ & $\mathrm{X}$ & $\mathrm{T}_{1}$ \\
Kontrol & $\mathrm{T}_{0}$ & - & $\mathrm{T}_{1}$ \\
\hline
\end{tabular}

Teknik pengumpulan data dalam penelitian adalah teknik test prestasi belajar. Data yang dikumpulkan diperoleh dari: (1). Data hasil nilai test soal ulangan asam basa sebagai data awal yang digunakan untuk uji homogenitas. (2). Nilai pretest dan posttest pada kelas eksperimen dan kelas kontrol (pokok bahasan kesetimbangan ion dan $\mathrm{pH}$ larutan garam) yang digunakan untuk uji hipotesis. Sedangkan teknik analisis data yang digunakan pada penelitian adalah uji-t. pengujian statistik dengan uji-t dapat dilakukan berdasarkan kriteria data yang berdistribusi normal. Oleh sebab itu, sebelum dilakukan pengolahan data, terlebih dahulu dilakukan uji normalitas menggunakan uji Liliefors. Jika harga Lmaks $<$ Ltabel, maka data berdistribusi normal. Harga Ltabel diperoleh dengan rumusan:

$$
L=\frac{0,886}{\sqrt{n}}
$$

Setelah data berdistribusi normal, kemudian dilakukan uji homogenitas dengan menguji varians kedua sampel (homogen atau tidak) terlebih dahulu dengan rumus:

$$
\mathrm{F}=\frac{\text { Varians Terbesar }}{\text { Varians Terkecil }}
$$

Kemudian dilanjutkan dengan uji kesamaan rata-rata menggunakan uji-t dua pihak untuk mengetahui kehomogenan kemampuan kedua sampel. Rumus uji-t pada uji homogenitas juga digunakan untuk melihat perubahan hasil belajar berupa prestasi belajar peserta didik antara kelas eksperimen dan kelas kontrol. Uji hipotesis yang digunakan merupakan uji-t pihak kanan dengan rumusan sebagai berikut:

$$
\frac{\overline{x_{1}}-\bar{x}_{2}}{S_{g} \sqrt{\frac{1}{n_{1}}+\frac{1}{n_{2}}}}
$$

Dengan Sg merupakan standar deviasi gabungan yang dapat dihitung menggunakan rumus:

$$
S_{g}=\frac{\frac{\left(n_{1}-1\right) S_{1}{ }^{2}+\left(n_{2}-1\right) S_{2}{ }^{2}}{n_{1}+n_{2}-2}}{2}
$$

Untuk menunjukkan kategori peningkatan prestasi belajar peserta didik dengan penerapan model pembelajaran Osborn dilakukan uji gain ternormalisasi $(N-$ Gain $)$ dengan rumus sebagai berikut:

$$
\mathrm{g}=\frac{\text { Skor posttest }- \text { skor pretest }}{\text { Skor maksimum-skor pretest }}
$$


Untuk melihat kategori nilai $\mathrm{N}$ - Gain ternomalisasi dapat dilihat pada Tabel 3.

Tabel 3. Nilai N - Gain Ternormalisasi Dan Kategori (Hake, 1998)

\begin{tabular}{cc}
\hline Rata-rata $N$-Gain ternormalisasi & Kategori \\
\hline$N$-Gain $\geq 0,70$ & Tinggi \\
$0,30 \leq N$-Gain $<0,70$ & Sedang \\
$N$-Gain $<0,30$ & Rendah \\
\hline
\end{tabular}

\section{HASIL}

\subsection{Uji Homogenitas}

Sebelum dilakukan uji homogenitas terlebih dahulu dilakukan uji normalitas soal ulangan asam basa karena data yang digunakan untuk uji homogenitas dalam penelitian adalah data yang diperoleh dari nilai soal ulangan asam basa yang telah terdistribusi normal. Hasil analisis uji normalitas dapat dilihat pada Tabel 3.

Tabel 4. Hasil Uji Normalitas

\begin{tabular}{cccccccc}
\hline Data & Kelas & $\boldsymbol{N}$ & $\overline{\mathbf{X}}$ & $\mathbf{S}$ & Lmaks & Ltabel & Keterangan \\
\hline Nilai & XI IPA 1 & 33 & 63,94 & 10,74 & 0,10 & 0,15 & Berdistribusi Normal \\
$\begin{array}{c}\text { ulangan } \\
\text { asam basa }\end{array}$ & XI IPA 3 & 30 & 64 & 12,06 & 0,10 & 0,16 & Berdistribusi Normal \\
\hline
\end{tabular}

Berdasarkan Tabel 4 dapat dilihat bahwa dari empat kelas 3 kelas berdistribusi normal yaitu kelas XI IPA 1, XI IPA 2, dan XI IPA 3 dimana harga $\mathrm{L}_{\text {maks }}<\mathrm{L}_{\text {tabel. }}$ Selanjutnya data diuji variansnya kemudian diuji kesamaan rata-rata dua pihak untuk mengetahui kehomogenan kedua kelas. Uji varians dilakukan sebagai syarat dari uji homogenitas, karena data yang diuji harus mempunyai varians yang sama. Hasil pengolahan data uji homogenitas dapat dilihat pada Tabel 5.

Tabel 5. Hasil Pengolahan Data Uji Homogenitas

\begin{tabular}{ccccccccc}
\hline Kelas & $\boldsymbol{N}$ & $\sum \boldsymbol{X}$ & $\overline{\mathbf{X}}$ & $\mathbf{F}$ tabel & Fhitung & tabel & thitung & Keterangan \\
\hline XI IPA 1 & 33 & 2110 & 63,94 & 1,82 & 1,26 & 1,67 & 0,02 & Homogen \\
dan & 30 & 1920 & 64 & & & & & \\
XI IPA 3 & & & & & & & & \\
\hline
\end{tabular}

Berdasarkan Tabel 5 dapat dilihat bahwa untuk masing-masing pasangan kelas yang diuji homogenitasnya terdapat 3 pasangan kelas yang homogennya yaitu kelas XI IPA 1 dengan XI IPA 2, kelas XI IPA 1 dengan XI IPA 3 dan kelas XI IPA 2 dengan XI IPA 3. Tiga pasangan kelas yang homogen ini menyatakan bahwa pasangan kelas tersebut layak untuk dilakukan penelitian dengan memilih satu pasangan kelas yang dilakukan secara acak (diundi) untuk dijadikan kelas eksperimen dan kontrol dan diperoleh kelas XI IPA 1 sebagai kelas eksperimen dan kelas XI IPA 3 sebagai kelas kontrol.

\subsection{Uji Hipotesis}

Data yang digunakan untuk uji hipotesis dalam penelitian adalah selisih antara nilai pretest dan posttest yang menunjukkan besarnya peningkatan prestasi peserta didik sebelum dan sesudah mempelajari materi kesetimbangan ion dan $\mathrm{pH}$ larutan garam dengan dan tanpa menggunakan model pembelajaran Osborn. Sebelum dilakukan uji hipotesis data pretest dan 
postest dinormalkan terlebih dahulu. Hasil pengolahan data normalitas dapat dilihat pada Tabel 6 dan uji hipotesis dapat dilihat pada Tabel 7.

Tabel 6. Uji Normalitas data Pretest dan Postest

\begin{tabular}{|c|c|c|c|c|c|c|c|}
\hline \multicolumn{7}{|c|}{ Pretest Kelas Kontrol } & \\
\hline $\mathbf{X i}$ & $\mathbf{f}$ & $\mathbf{F}$ & $\mathbf{F z}=\mathbf{F} / \mathbf{N}$ & $\begin{array}{c}\mathbf{Z}=(\mathbf{X i -} \\
\mathbf{x}) / \mathbf{S}\end{array}$ & $\begin{array}{c}\mathbf{Z}_{\text {tabel }} \\
(\mathbf{P} \leq \mathbf{Z})\end{array}$ & $\begin{array}{c}\mathbf{L}= \\
(\mathbf{F z}- \\
\mathbf{P} \leq \mathbf{Z})\end{array}$ \\
\hline $\mathbf{8}$ & 1 & 1 & 0,03333 & $-2,21$ & 0,0136 & 0,01973 \\
\hline $\mathbf{1 2}$ & 1 & 2 & 0,06667 & $-1,76$ & 0,0392 & 0,02747 \\
\hline $\mathbf{1 6}$ & 2 & 4 & 0,13333 & $-1,31$ & 0,0951 & 0,03823 \\
\hline $\mathbf{2 0}$ & 5 & 9 & 0,30000 & $-0,86$ & 0,1949 & 0,1051 \\
\hline $\mathbf{2 4}$ & 5 & 14 & 0,46667 & $-0,41$ & 0,3409 & 0,12577 \\
\hline $\mathbf{2 8}$ & 3 & 17 & 0,56667 & 0,02 & 0,508 & 0,05867 \\
\hline $\mathbf{3 2}$ & 5 & 22 & 0,73333 & 0,47 & 0,6808 & 0,05253 \\
\hline $\mathbf{3 6}$ & 3 & 25 & 0,83333 & 0,92 & 0,8212 & 0,01213 \\
\hline $\mathbf{4 0}$ & 5 & 30 & 1,00000 & 1,37 & 0,9147 & 0,0853 \\
\hline
\end{tabular}

Pretest Kelas Eksperim en :

\begin{tabular}{|c|c|c|c|c|c|c|}
\hline $\mathbf{X i}$ & $\mathbf{F}$ & $\mathbf{F}$ & $\mathbf{F z}=\mathbf{F} / \mathbf{N}$ & $\begin{array}{c}\mathbf{Z}= \\
(\mathbf{X i}- \\
\overline{\mathbf{x}}) / \mathrm{S}\end{array}$ & $\begin{array}{r}\mathbf{Z}_{\text {tabel }} \\
(\mathbf{P} \leq \mathbf{Z})\end{array}$ & $\begin{array}{c}\mathbf{L}= \\
(\mathbf{F z}- \\
\mathbf{P} \leq \mathbf{Z})\end{array}$ \\
\hline 12 & 2 & 2 & 0,0606 & $-1,76$ & 0,0392 & 0,02141 \\
\hline 16 & 4 & 6 & 0,1818 & $-1,29$ & 0,0985 & 0,08332 \\
\hline 20 & 2 & 8 & 0,2424 & $-0,83$ & 0,2033 & 0,03912 \\
\hline 24 & 8 & 16 & 0,4848 & $-0,36$ & 0,3594 & 0,12545 \\
\hline 28 & 5 & 21 & 0,6364 & 0,09 & 0,5359 & 0,10046 \\
\hline 32 & 4 & 25 & 0,7576 & 0,56 & 0,7123 & 0,04528 \\
\hline 36 & 5 & 30 & 0,9091 & 1,03 & 0,8485 & 0,06059 \\
\hline 40 & 1 & 31 & 0,9394 & 1,49 & 0,9319 & 0,00749 \\
\hline 44 & 2 & 33 & 1,0000 & 1,96 & 0,975 & 0,025 \\
\hline
\end{tabular}

\begin{tabular}{ccccccc}
\multicolumn{7}{c}{ Postest Kelas Kontrol } \\
\hline $\mathbf{X i}$ & $\mathbf{F}$ & $\mathbf{F}$ & $\mathbf{F z}=\mathbf{F} / \mathbf{N}$ & $\begin{array}{c}\mathbf{Z}=(\mathbf{X i}- \\
\mathbf{x}) / \mathbf{S}\end{array}$ & $\begin{array}{c}\mathbf{Z}_{\text {tabel }} \\
(\mathbf{P} \leq \mathbf{Z})\end{array}$ & $\begin{array}{c}\mathbf{L}=(\mathbf{F z}- \\
\mathbf{P} \leq \mathbf{Z})\end{array}$ \\
\hline $\mathbf{4 0}$ & 1 & 1 & 0,03333 & $-3,08$ & 0,001 & 0,03233 \\
$\mathbf{5 2}$ & 1 & 2 & 0,06667 & $-1,94$ & 0,0262 & 0,04047 \\
$\mathbf{6 4}$ & 5 & 7 & 0,23333 & $-0,80$ & 0,2119 & 0,02143 \\
$\mathbf{6 8}$ & 5 & 12 & 0,40000 & $-0,43$ & 0,3336 & 0,06640 \\
$\mathbf{7 2}$ & 5 & 17 & 0,56667 & $-0,05$ & 0,4801 & 0,08657 \\
$\mathbf{7 6}$ & 2 & 19 & 0,63333 & 0,32 & 0,6255 & 0,00783 \\
$\mathbf{8 0}$ & 4 & 23 & 0,76667 & 0,70 & 0,758 & 0,00867 \\
$\mathbf{8 4}$ & 6 & 29 & 0,96667 & 1,08 & 0,8599 & 0,10677 \\
$\mathbf{8 8}$ & 1 & 30 & 1,00000 & 1,46 & 0,9279 & 0,07210 \\
\hline
\end{tabular}

Postest Kelas Eksperimen

\begin{tabular}{ccccccc}
\hline $\mathbf{X i}$ & $\mathbf{F}$ & $\mathbf{F}$ & $\mathbf{F z}=\mathbf{F} / \mathbf{N}$ & $\begin{array}{c}\mathbf{Z}=(\mathbf{X i}- \\
\mathbf{x}) / \mathbf{S}\end{array}$ & $\begin{array}{c}\mathbf{Z}_{\text {tabel }} \\
(\mathbf{P} \leq \mathbf{Z})\end{array}$ & $\begin{array}{c}\mathbf{L}= \\
(\mathbf{F z}- \\
\mathbf{P} \leq \mathbf{Z})\end{array}$ \\
\hline 60 & 2 & 2 & 0,0606 & $-2,16$ & 0,0154 & 0,04521 \\
64 & 1 & 3 & 0,0909 & $-1,74$ & 0,0409 & 0,05001 \\
72 & 6 & 9 & 0,2727 & $-0,92$ & 0,1788 & 0,09393 \\
76 & 2 & 11 & 0,3333 & $-0,51$ & 0,305 & 0,02833 \\
80 & 4 & 15 & 0,4545 & $-0,09$ & 0,4641 & - \\
84 & 9 & 24 & 0,7273 & 0,31 & 0,6217 & 0,00955 \\
88 & 4 & 28 & 0,8485 & 0,72 & 0,7644 & 0,08408 \\
92 & 1 & 29 & 0,8788 & 1,13 & 0,8708 & 0,00799 \\
96 & 4 & 33 & 1,0000 & 1,54 & 0,9382 & 0,06180 \\
\hline
\end{tabular}

Tabel 7. Hasil Uji Hipotesis

\begin{tabular}{cccccccc}
\hline Kelas & $\boldsymbol{N}$ & $\sum \boldsymbol{X}$ & $\overline{\mathbf{X}}$ & $\mathbf{S}_{\text {gab }}$ & ttabel & thitung & Keterangan \\
\hline Ekperimen & 33 & 1776 & 53,82 & \multirow{2}{*}{4,94} & \multirow{2}{*}{1,67} & 7,24 & Hipotesis \\
Kontrol & 30 & 1344 & 44,80 & & & & diterima \\
\hline
\end{tabular}

Uji hipotesis yang didapat dari selisisih nilai pretest-postest dilakukan dengan menggunakan uji t pihak kanan, hasil uji hipotesis thitung $=7,24$ dan nilai tabel pada $\alpha=0,05$ dengan $\mathrm{dk}=61$ adalah 1,67 artinya thitung lebih besar daripada tabel yaitu 7,24 > 1,67 sehingga hipotesis diterima, artinya peningkatan prestasi belajar peserta didik dengan penerapan model pembelelajaran Osborn dapat diterima.

\subsection{Menentukan Gain Ternormalisasi ( $N$-gain)}

Kategori peningkatan prestasi belajar peserta didik dihitung dengan menggunakan persamaan $\mathrm{N}$-Gain untuk kelas eksperimen dan kelas kontrol. Hasil uji $\mathrm{N}$-Gain menunjukkan bahwa pada kelas eksperimen diperoleh rata-rata $\mathrm{N}$-Gain sebesar 0,73 yang termasuk kategori tinggi, sedangkan untuk kelas kontrol adalah 0,62 yang termasuk kategori sedang. 


\section{PEMBAHASAN}

Penelitian dilakukan di kelas XI IPA SMAN 14 Pekanbaru untuk melihat peningkatan prestasi belajar peserta didik pada pokok bahasan kesetimbangan ion dan $\mathrm{pH}$ larutan garam dengan menerapkan model pembelajaran Osborn. Didapatkan bahwa penerapan model pembelajaran Osborn dapat meningkatkan prestasi belajar peserta didik pada pokok bahasan keseimbangan ion dan $\mathrm{pH}$ larutan garam dengan kategori peningkatan tinggi yaitu 0,73. Hal ini sesuai dengan penelitian Mareza, dkk (2017) bahwa penerapan model pembelajaran Osborn dapat meningkatkan hasil belajar peserta didik pada pokok bahasan koloid dengan persentase ketuntasan hasil belajar sebesar $81,25 \%$.

Prestasi belajar peserta didik melalui penerapan model pembelajaran Osborn dapat meningkat dikarenakan model pembelajaran Osborn dapat memfasilitasi peserta didik mencari, menemukan dan membangun pengetahuannya untuk menyelesaikan permasalahan. Model pembelajaran Osborn juga dapat menciptakan situasi belajar yang melibatkan peserta didik belajar secara aktif membangun pengetahuannya sendiri dan menemukan konsep-konsep pelajaran yang baru sehingga pengetahuan yang diperolehnya lebih bermakna dan dapat bertahan dalam jangka waktu yang panjang. Hal ini sesuai dengan pendapat Wina Sanjaya (2010) bahwa pengetahuan yang dibangun sendiri oleh peserta didik akan menjadi pengetahuan yang bermakna, sedangkan pengetahuan yang hanya diperoleh melalui proses pemberitahuan tidak akan menjadi pengetahuan bermakna. Selain itu, menurut pendapat Bruner yang dikutip oleh Trianto (2014) bahwa berusaha sendiri untuk mencari pemecahan masalah serta pengetahuan yang menyertainya menghasilkan pengetahuan yang benar-benar bermakna. Suatu konsekuensi logis karena dengan berusaha untuk mencari pemecahan masalah secara mandiri akan memberikan suatu pengalaman konkret. Dengan pengalaman itu dapat digunakan pula untuk memecahkan masalah serupa yang dapat memberikan makna tersendiri kepada peserta didik.

Model pembelajaran Osborn berorientasi pada pemecahan masalah yang meliputi enam tahap, yaitu Orientasi, analisa, hipotesis, pengeraman, sintesis dan verifikasi. Pembelajaran berdasarkan masalah terdiri dari menyajikan kepada peserta didik situasi masalah yang autentik dan bermakna yang dapat memberikan kemudahan kepada mereka untuk melakukan penyelidikan. Peserta didik dituntut berperan aktif dalam setiap tahapan dari model pembelajaran Osborn. Tahap orientasi guru memberikan permasalahan kepada peserta didik berupa wacana yang berhubungan dengan fenomena-fenomena yang berhubungan dengan topik pembelajaran. Adanya wacana merupakan cara guru untuk menciptakan situasi yang baru dan dapat memotivasi peserta didik sehingga peserta didik menjadi termotivasi dan dapat meningkatkan prestasi belajarnya. Hal ini sesuai dengan pendapat Damis dan Muhajis (2018) bahwa motivasi belajar erat kaitannya degan prestasi belajar peserta didik, semakin tinggi motivasi belajar peserta didik maka semakin besar pula peluang untuk mencapai prestasi belajar yang baik atau tinggi.

Tahap kedua adalah tahap analisa. Pada tahap ini, peserta didik dituntut untuk mengidentifikasi masalah secara mandiri, sehingga peserta didik akan terlibat aktif dalam pembelajaran dan prestasi belajar peserta didik dapat meningkat. Menurut Hisyam Zaini (2009) jika peserta didik terlibat aktif dalam pembelajaran, maka kesan penerimaan pelajaran akan melekat lebih lama. Pada tahap analisa ini membantu peserta didik dalam membangun pengetahuannya, hal ini dikarenakan pada tahap analisa peserta didik dilatih untuk menyelidiki fenomena dan mencari permasalahan yang ada. Misalnya pada pertemuan pertama peserta didik mengidentifikasi fenomena mengenai seseorang yang menderita sakit maag (asam lambung naik) dan diberi obat maag.

Tahap ketiga adalah tahap hipotesis, tahap hipotesis berpusat pada permasalahan spesifik yang ditetapkan pada tahap analisa dan mengharuskan peserta didik untuk menghasilkan dan menerapkan rencana mereka untuk memperoleh suatu jawaban. Pada tahap ini peserta didik bekerja 
secara individu membuat hipotesis dari rumusan masalah yang telah dibuat. Hipotesis peserta didik pada dasarnya disusun berdasarkan pengetahuan yang telah dimilikinya dan dikaitkan dengan permasalahan yang telah dirumuskan. Dalam tahap ini peserta didik diberi kebebasan untuk menyusun dugaannya sehingga dapat meningkatkan prestasi belajar peserta didik seperti yang dikemukakan oleh Mutiara Zanzibar (2015) pada kegiatan menyusun hipotesis menuntut peserta didik menghasilkan gagasan dan jawaban yang bervariasi dalam menjawab pertanyaan.

Selanjutnya di tahap pengeraman peserta didik berdiskusi bersama teman kelompoknya untuk mencari hipotesis yang paling benar sesuai dengan rumusan masalah yang ada kemudian peserta didik menuliskan pada kolom pengeraman. Pada tahap pengeraman peserta didik terlihat lebih aktif dalam mengemukakan pendapat yang ada sehingga lebih mudah memahami materi dan dapat meningkatkan prestasi belajar. Hal ini sesuai dengan pendapat Suharsimi Arikunto (2002) bahwa adakalanya seorang peserta didik lebih mudah merima keterangan yang diberikan oleh teman sebangku atau teman yang lain karena tidak ada rasa enggan atau malu untuk bertanya.

Tahap kelima adalah sintesis, pada tahap ini peserta didik merencanakan pemecahan masalah melalui percobaan atau penyelidikan pustaka, mengumpulkan data dan menganalisis informasi yang berkaitan dengan permasalahan. Peserta didik dibimbing oleh guru dalam mencari solusi dan melaksanakan pemecahan masalah dengan mengerjakan LKPD untuk menemukan jawaban permasalahan yang telah diidentifikasi secara diskusi kelompok. Oleh karena itu, tahap sintesis memiliki peranan penting dalam membantu peserta didik mengembangkan kemampuan pemecahan masalah sehingga dapat meningkatkan prestasi belajar peserta didik.

Tahap terakhir dalam model Osbron adalah Verifikasi. Pada tahap verifikasi melibatkan peserta didik pada mengkomunikasikan jawaban dari permasalahan yang ada pada tahap sintesis. Peserta didik menyampaikan hasil dari penyelidikan yang dilakukannya di depan kelas. Dalam tahap ini kelompok yang menjadi audiens berkesempatan untuk memberi penilaian terhadap hasil pekerjaan kelompok lain, memberikan dan menerima saran, serta berlatih untuk mengkomunikasikan apa yang ada dalam pikirannya.

\section{KESIMPULAN DAN REKOMENDASI}

\section{A. Kesimpulan}

Berdasarkan hasil penelitian dan pembahasan dapat disimpulkan bahwa penerapan model pembelajaran Osborn dapat meningkatkan prestasi belajar peserta didik pada pokok bahasan kesetimbangan ion dan $\mathrm{pH}$ larutan garam di kelas XI IPA SMAN 14 Pekanbaru dan peningkatan prestasi belajar peserta didik pada pokok bahasan kesetimbangan ion dan $\mathrm{pH}$ larutan garam di kelas XI IPA SMAN 14 Pekanbaru melalui model pembelajaran Osborn berada pada kategori tinggi dengan $\mathrm{N}$-gain sebesar 0,73 .

\section{B. Rekomendasi}

Berdasarkan kesimpulan yang diperoleh, peneliti merekomendasikan kepada guru bidang studi kimia dapat menjadikan model pembelajaran Osborn sebagai salah satu alternatif model pembelajaran untuk meningkatkan prestasi belajar peserta didik khususnya pada pokok bahasan kesetimbangan ion dan $\mathrm{pH}$ larutan garam.

\section{DAFTAR PUSTAKA}

Agus Irianto. 2003. Statistika Konsep Dasar dan Aplikasi. Kencana. Jakarta.

Damis dan Muhajis. 2018. Analisis Hubungan Antara Motivasi Belajar dengan Hasil Belajar Siswa Pada Sekolah Dasar Negeri 3 Allakuang Kecamaran Maritengngae Kabupaten Sidenreng 
Rappang. Jurnal Idaarah. 2(2):216-228. Fakultas Agama Islam Universitas Timur. Makassar

Hake, R.R. 1998. Interactive-engagement vs traditional methods : A six-thousand-student survey of mechanics test data for introductory physics courses. Am. J. Phys

Hisyam Zaini. 2009. Strategi Pembelajaran Aktif Implementasi dan Kendalanya di Dalam Kelas. Seminar Lokakarya Nasional Pendidikan Biologi. 18 Juli 2009. FKIP UNS. Surakarta

Luthfiyati N.A, Elah Nurlaela,Dian Usdiyana. 2016. Model Pembelajaran Osborn Untuk Meningkatkan Kemampuan Pemecahan Masalah Matematis Siswa. Jurnal Matematika dan Pendidikan Matematika 1(2):93-102. Universitas Wiralodra. Indramayu

Mareza Diantari, M. Hasan, dan Habibati. 2017. Penerapan Model Pembelajaran Osborn Untuk Meningkatkan Prestasi belajar Peserta didik Pada Materi Koloid di Kelas XI IPA 1 SMAN 1 Indrapuri. Jurnal Ilmiah Mahasiswa Jurusan Pendidikan Kimia 3(1):22-31. Universitas Syiah Kuala. Banda Aceh.

Mutiara Zanzibar. 2015. Penerapan Model Pembelajaran Inkuiri Terbimbing Melalui Kegiatan Field Trip ke Bangka Botanical Garden (BBG) Untuk Meningkatkan Keterampilan Berpikir Kreatif Siswa. Prosiding Simposium Nasional Inovasi dan Pembelajaran Sains 2015. 8 dan 9 Juni 2015. ITB. Bandung.

Roestiyah N.K. 2012. Strategi Belajar Mengajar. Rineka Cipta. Jakarta.

Sudjana. 2005. Metoda Statistika. Tarsito. Bandung.

Suharsimi Arikunto. 2013. Dasar-dasar Evaluasi Pendidikan. Bumi Aksara. Jakarta.

Suparno, P. 2007. Metodologi Pembelajaran Fisika Konstruktivisme dan Menyenangkan. USD. Yogyakarta.

Trianto. 2014. Model Pembelajaran Terpadu. Bumi Aksara. Jakarta.

Wina Sanjaya. 2011. Penelitian Tindakan Kelas. Kencana Prenada Media Grup. Jakarta. 